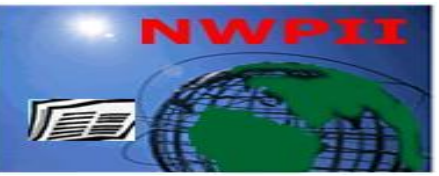

American Journal of Biomedical Sciences

ISSN: 1937-9080

nwpii.com/ajbms

\title{
Techniques for Genetic Analysis of Non Syndromal Cleft Lip/Palate: A Review
}

\author{
Varun Pratap Singh ${ }^{1}$, Deepak Kumar Roy ${ }^{2}$, Pramita Suwal ${ }^{3}$, Ashok Ayer ${ }^{4}$, \\ Prabhat Ranjan Pokharel ${ }^{5}$, Dinesh M.R. ${ }^{6}$
}

${ }^{1}$ Assistant Professor \& In charge, Department of Orthodontics \& Dentofacial Orthopaedics, College of Dental Surgery, BPKIHS, Dharan, Nepal.

${ }^{2}$ Dental Surgeon, Dharan, Nepal.

${ }^{3}$ Associate Professor \& Head, Department of Prosthodontics, Crown \& Bridge, College of Dental Surgery, BPKIHS, Dharan, Nepal

${ }^{4}$. Post Graduate, Dept. of Endodontics \& Conservative Dentistry, College of Dental Surgery, BPKIHS, Dharan, Nepal.

${ }^{5}$ Assistant Professor, Department of Orthodontics \& Dentofacial Orthopaedics, College of Dental Surgery, BPKIHS, Dharan, Nepal.

${ }^{6}$ Professor \& Head, Dept. of Orthodontics, D.A.P.M.R.V. Dental College \& Hospital, Bangalore, Karnataka, India.

*Corresponding Author:

Dr. Varun Pratap Singh

Assistant Professor \& In charge

Department of Orthodontics \& Dentofacial Orthopaedics

College of Dental Surgery, BPKIHS

Dharan, Nepal

Email: varundc@gmail.com

Received: 31 December 2011; | Revised: 18 March 2012; | Accepted: 12 April 2012

\begin{abstract}
The formation of craniofacial structures during embryonic development involves various complex molecular pathways. Disturbances in these pathways either due to genetic or environmental factors may lead to orofacial clefts. Approximately two thirds of the cases are not accompanied by other anomalies and are called non syndromic. The etiology seems complex, but genetics plays a major role. With the advances in molecular biology and genetics such studies are more refined than ever before and various candidate genes have been associated with Non Syndromal cleft lip/palate in different populations. There are various techniques and models used by different investigators across the globe. In this review we intend to describe most common approaches towards genetic analysis of Non syndromic cleft and try to evaluate the merits and demerits of a particular approach.
\end{abstract}

Keywords: Association studies, cytogenetics, linkage disequilibrium, Non syndromic cleft lip/palate. 


\section{Introduction}

Cleft lip/palate (CL/P) is one of the most common congenital anomaly in humans. Its global prevalence is estimated to be ranging from $1 / 300$ to $1 / 2500$ births with racial and ethnic diversity. ${ }^{1}$ The etiology of CL/P is multifactorial involving both genetic and environmental factors, including a possible mutual interaction. Various environmental factors like alcohol intake, cigarette smoking and nutritional deficiencies have been implicated. ${ }^{2}$ Although environmental factors have shown to play a role, they however have shown a weak association and no single study is attributed to environmental factors as the sole etiology for non Syndromal cleft lip and palate (NSCLP).

Genetics of craniofacial development has undergone tremendous advances; numerous genetic pathways are shown to be involved in craniofacial development. There are many genes that have been linked with NSCLP like MSX1, TGFB3, TGFA, IRF6, RARA, MTHFR,GABRB3, BCL3,WNT and the list is ever increasing with the latest development in this field. ${ }^{1,3,5}$

There are various techniques that have been employed in the genetic investigations for NSCLP, the purpose of this review is to present and compare their utility.

\section{Animal studies}

The mouse model is the most commonly used model, because of "its small size, short reproductive cycle, known genetic information, and, most importantly, because of the ability to introduce precise genetic alterations into mouse embryonic stem cells and transfer them to stable mouse lines" 9. There are many approaches to study NSCLP using animal models. Various inbred mice strain models show spontaneous clefting like A/WySn, A/J, A/HeJ. ${ }^{10}$ The teratogenic effect was also evaluated in few studies that indicated greater frequencing of clefting in the ICR and $\mathrm{A} / \mathrm{J}$ mice strain. It is interesting to note that $\mathrm{A} / \mathrm{J}$ strain showed spontaneous clefting but the incidence of clefting increased with the effect of teratogen. ${ }^{11,12}$
To determine that a gene contributes to the clefting, targeted gene studies can be done in mouse models. Various knockout models were developed for target genes. If we see for MSX1 gene such knockout models have shown a role of MSX1 gene in normal development of the palate and all homozygotes for MSX1 show multiple craniofacial anomalies including cleft lip/palate. ${ }^{13,14}$ In similar studies TGFB3 null mutant mice showed cleft of the palate, however unlike other models there were no other craniofacial anomalies. ${ }^{15,16} \mathrm{~A}$ study with mice deficient for IRF6 showed craniofacial developmental abnormalities including orofacial clefts and other skin and lung anomalies. ${ }^{17}$ This type of targeted gene approach has been useful to study target genes for non Syndromal cleft lip/palate in mice and as homologous genes on humans are known, significant correlation can be established with various pathological conditions. This approach has been very useful and it has provided information regarding gene function but concerns have been raised about implication of these results to human. In a detailed review Thyagarajan et $\mathrm{al}^{9}$ described the controversy in following headings: "Genetic background, Early lethality of animals, Differences in the life spans of humans and mice, Interference by a selection marker gene, Compensatory genetic loci, Functional redundancy in the in vivo and in vitro conditions."

\section{Linkage studies and linkage disequilibrium test on human subjects}

Linkage studies are very useful in analyzing a particular allele for a genetic disease. The linkage disequilibrium test, a modified form of linkage study overcomes the disadvantages of linkage studies in that "it only considers parents who are heterozygous for the marker allele that is considered responsible for the pathology, so it does not need data from multiple affected family members or unaffected siblings." ${ }^{18}$ In this regard it is worth mentioning a metaanalysis by Marazita et $\mathrm{al}^{19}$ which combined the results of 13 studies on different population subgroups. The results indicated that six regions on five chromosomes had significant linkage with HLOD>3.2. 
(chromosomes 1p12-13, 6p23, 6q23-25, 9q21, $14 q 21-24$, and 15q15). These loci can be used to identify or screen the candidate genes that may be associated with NSCLP. A study on four different populations showed a significant linkage with respect to $4 \mathrm{p} 16$ region. This study also suggested that other than MSX1, other genes in this region can also influence risk of orofacial clefts. ${ }^{20}$ Two recent studies also suggest $6 \mathrm{p} 24$ and $6 \mathrm{q}$ as important regions influencing cleft risk in humans. $^{21,22}$

The disadvantages of Linkage studies is that they require large multiplex families and it is difficult to study diseases like NSCLP which has shown to be a polygenic disorder with several regions and even after identification of the chromosomal region, it is very difficult to identify a particular candidate gene as several genes may be present in that region. ${ }^{18,20}$

\section{Association studies}

The Association studies can be either of a family based design or a case control design. The case control design is most commonly used and preferred one because of simpler methodology, easier to get cases and controls as compared to families, easier to gather a large number of samples, disease allele frequency, penetrance and attributable risk can be studied altogether. ${ }^{23}$ These association studies in various populations have linked MSX1, TGFB3, RARA, BCL3, TGFA, IRF6, MTHFR, RARA, GABRB3, WNT ${ }^{1,3-4,5-8 .}$

There are a lot of association studies in the literature with varying results. A good example is Msx1 P147Q variant which was associated with NSCLP in a Malay ${ }^{24}$, Chinese $^{25}$ and Vietnamese ${ }^{26}$ population whereas there was no association detected in Thai $^{27}$ population. Many of such studies have attributed different candidate genes in different populations. The absence of consistency in results is related to poor statistical power, biological and phenotypic complexity, populationspecific linkage disequilibrium, effect-size bias, and population stratification. "Undetected population stratification has caused the most concern and is an issue for direct candidate-gene approaches". 23

\section{Cytogentic studies}

Cytogenetic studies are useful in detecting chromosomal aberrations. A study done on Indian patients utilizing GTC banding and Fluorescence in-situ hybridization showed that out of 10 cases, 9 cases were with normal karyotype and one was with trisomy-18. ${ }^{28}$ In a similar study in Kuwait, out of 56 cases only 2 with chromosomal aberration were detected, one showed 47, XYY while the other revealed partial trisomy of 22(47, XX, +22del.q 13(qter)). ${ }^{29}$ Alkuraya and colleagues found that a chromosomal translocation in a cleft lip/palate patient disrupts the SUMO1 gene. Later in mice they found that SUMO1 was expressed in developing lip and palate. ${ }^{30}$

One of the cytogenic technique is Array comparative genomic hybridisation (array-CGH). A study by Osoegawa et $\mathrm{al}^{31}$ describes the utility of this technique. "Array-CGH has evolved as a method to identify and map sub-microscopic deletions/duplications simultaneously onto the genome sequence. Identification of microdeletions using array-CGH has proven to be a very powerful strategy to narrow down candidate disease gene regions for subsequent gene hunting.'Further the results of the study stated that out of 104 nonsyndromic cases there was one subject with a $3.2 \mathrm{Mb}$ deletion at chromosome 6q25.1-25.2 and another with a $2.2 \mathrm{Mb}$ deletion at 10q26.11-26.13. "Analyses of parental DNA demonstrated that the two deletion cases at 22q11.21 and 6q25.1-25.2 were de novo, the deletion of 10q26.11-26.13 was inherited from the mother, who also has a cleft lip".

The problem with above mentioned cytological studies is that there is a weak evidence of chromosomal aberration in NSCLP patients; however they can serve to narrow down the hunting region for candidate genes.

\section{Expression studies}

This is a growing field and expression profiles in cleft lip/palate patient can provide a clue towards the genetic pathways affected leading to the identification of candidate genes. 
In one of the landmark expression studies done by Mukhopadhyay et al; ${ }^{32}$ out of 12,000 genes studied, expression of 158 genes encoding various growth and differentiation factors was found differentially altered in murine orofacial development. The genes in this category included growth factors, growth factor receptors, cytokines, and hormones.

An expression study using gene chip analysis revealed a higher expression of osteopontin $(S P P 1)$, chemokine receptor $4(C X C R 4)$ and serglycin $(P R G 1)$ in cleft lip/palate patients supporting the role of these genes in NSCLP. ${ }^{33}$

The Craniofacial and Oral Gene Expression Network (COGENE) is gene expression profile database created by consortium of investigators involved in describing human gene expression research and is used for comparison in studies of craniofacial anomalies. ${ }^{34}$

The expression studies have a limitation in that the expression profiles which are recorded in the patients may not be a true reflection of the expression which happened during development of the defect as the expression may have ended/altered due to the time factor ${ }^{33}$

\section{Syndromic CL/P cases}

Although this article is about NSCLP, it is worth mentioning Syndromic form also as there is an evidence that genes associated with Syndromic form may contribute to NSCLP. Satnier and Moore $^{35}$ have proposed TBX22, PVRLI1, IRF6, P63, MSX1, FGFR1,FOXC2, TTF2 as genes associated with both Syndromic forms and NSCLP. It would be a useful idea to study genetics of Syndromic cleft lip/palate and the results can then be screened for NSCLP. However, it is probably not as simple as that, because numerous syndromic forms of cleft lip/palate are described in the literature and to get a significant sample size is an issue, further both coding and non-coding regions can contribute to NSCLP.

\section{Conclusion}

No approach is always better than the other. Every technique has its merits and demerits. It is very important to choose the correct approach for studying the specific problem. Studies on different approaches may be clubbed together to gain important information regarding NSCLP.

\section{Acknowledgements}

Authors thank Dr. R.K. Singh and Dr. T.R. Manindhar for their valuable guidance and $\mathrm{Mr}$. Shyam Paudel for English language corrections.

\section{References}

1. Morkuniene A, Steponaviciute D, Ambrozaityte L, Utkus A, Linkeviciane L,Kucinskas V. TGFA, TGFB3, GABRB3, RARA and BCL3 loci associated with nonsyndromic orofacial clefts? A Lithuanian study, Biologija, 2007,18(1),1-6

2. Wong FK, Hagg U. An Update on the etiology of Orofacial Clefts. Hong Kong Med J,2004,10(5), 331-36.

3. Singh VP, Ramu D. Association of MSX1 799>T variant with nonsyndromic cleft lip/palate in South Indian adolescent patients. Int J Paediatr Dent, 2011 ,Oct 4. Doi: 10.1111/j.1365-263X.2011.01184.X.

4. Singh VP, Ramu MD, Amarnath BC, Dharma RM, Chikanayaka P, Shetty KR. Association of TGFB3 rs2300607 (IVSI+ 5321) Gene Variant with Non Syndromic Cleft Lip/Palate in South Indian Patients. Am. J. Biomed. Sci, 2011, 3(3), 236-240. Doi: 10.5099/aj110300236.

5. Jagoma“gi T, Nikopensius T, Krjuts`kov K, Tammekivi V, Viltrop $\mathrm{T}$, Saag $\mathrm{M}$ et al. MTHFR and MSX1 contribute to the risk of nonsyndromic cleft lip/palate, Eur J Oral Sci, 2010, 118, 213-220. Doi: 10.1111/j.16000722.2010.00729.x

6. Jehee FS, Burin BA, Rocha KM, Zechi-Ceide $\mathrm{R}$, Bueno DF, Brito L et al. Novel mutations in IRF6 in nonsyndromic cleft lip with or without cleft palate: When should IRF6 mutational screening be done? Am J Med Genet Part A,2004, 149A, 1319-1322.
Doi: 10.1002/ajmg.a.32849

7. Park JY, Yoo HW, Kims Y. Genetic Analysis of TGFA, MTHFR, and IFR6 in Korean 
Patients Affected by Nonsyndromic Cleft Lip with or without Cleft Palate (CL/P). Genomics \& Informatics, 2007, 5(2),56-60.

8. Chiquet BT, Blanton SH, Burt A, Ma D, Stal $\mathrm{S}$, Mulliken JB, et al. Variation in WNT genes is associated with non-syndromic cleft lip with or without cleft palate. Hum Mol Genet 2008, 17, 2212-2218. doi: 10.1093/hmg/ddn121

9. Thyagarajan T, Totey S, Danton MJ, Kulkarni AB. Genetically altered mouse models: the good, the bad and the ugly, Crit Rev Oral Biol Med,2003,14, 154-74. Doi: $\underline{10.117 /}$ 1544111303014000302

10. Juriloff DM. Differences in frequency of cleft lip among the A strains of mice. Teratology 1982, 25, 361-368.

11. Nagao T, Fujikawa K. Male-mediated teratogenesis: spectrum of congenital malformations in the offspring of $\mathrm{A} / \mathrm{J}$ male mice treated with ethylnitrosourea. Teratog Carcinog Mutagen .1996, 16, 301-305. DOI: $\quad$ 10.1002/(SICI)1520-6866(1996)16:6 $\leq 301::$ AID-TCM2>3.0.CO;2-M

12. Yamada T, Fujiwara K, Mishima K, Sugahara T. Effect of ENU (ethylnitrosourea) mutagenesis in cleft lip and/or palate pathogenesis in mice. Int $\mathrm{J}$ Oral Maxillofac Surg 2005, 34, 74-77. DOI: 10.1016/j.ijom.2004.03.004

13. Satokata I, Maas R. Msxl deficient mice exhibit cleft palate and abnormalities of craniofacial and tooth development .Nat Genet.1994, 6, 348-356. DOI $: 10.1038 / \mathrm{ng} 0494-348$

14. Nugent P, Greene RM. MSX-1 gene expression and regulation in embryonic palatal tissue. In Vitro Cell Dev Biol Anim. 1998, 34(10),831-5. DOI: 10.1007/s11626-9980038-5

15. Proetzel G, Pawlowski SA, Wiles MV, Yin M, Boivin GP, Howles PN et al. Transforming growth factor- $\beta 3$ is required for secondary palate fusion. Nat Genet 1995, 11,409-414. doi:10.1038/ng1295-409

16. Kaartinen V, Voncken JW, Shuler C, Warburton $\mathrm{D}, \mathrm{Bu} \mathrm{D}$, Heisterkamp $\mathrm{N}$ et al. Abnormal lung development and cleft palate in mice lacking TGF-beta 3 indicates defects of epithelial-mesenchymal interaction. Nat
Genet.1995, $\quad 11, \quad 415-421$. doi:10.1038/ng1295-415

17. Ingraham CR, Kinoshita A, Kondo S, Yang B, Sajan S, Trout KJ et al. Abnormal skin, Limb and craniofacial morphogenesis in mice deficient for interferon regulatory factor 6 (Irf6). Nat Genet 2006, 38, 13351340. doi:10.1038/ng1903

18. Feng H, Sassani R, Bartlett SP, Lee A, Hecht JT, Malcolm S, etal. Evidence, from family studies, for linkage disequilibrium between TGFA and a gene fornonsyndromic cleft lip with or without cleft palate. Am J Hum Genet. 1994, 55(5),932-6.

19. Marazita ML, Murray JC, Lidral AC, ArcosBurgos M, Cooper ME, Goldstein $\mathrm{T}$ etal. Meta-analysis of 13 genome scans reveals multiple cleft lip/palate genes with novel loci on 9q21and 2q32-35. Am J Hum Genet.2004, $75,161-173$

20. Ingersoll RG, Hetmanski J, Park JW, Fallin $\mathrm{MD}, \mathrm{McIntosh} \mathrm{I}, \mathrm{Wu}-\mathrm{Chou} \mathrm{YH}$ et al. Association between genes on chromosome $4 p$ 16 and nonsyndromic oral clefts in four populations. Eur J Hum Genet, 2010 ,18(6),726-32. doi:10.1038/ejhg.2009.228

21. Salahshourifar I, Halim AS, Sulaiman WA, Zilfalil BA. Contribution of $6 \mathrm{p} 24$ to nonsyndromic cleft lip and palate in a Malay population: association of variants in OFC1. $\mathrm{J}$ Dent Res. 2011, 90(3),387-91. doi:10.1177/0022034510391798

22. Letra A, Menezes R, Fonseca RF, Govil M, McHenry T, Murphy MJ etal. Novel cleft susceptibility genes in chromosom e 6q. J Dent Res. 2010, 89(9), 92732. doi:10.1177/0022034510370004

23. Cardon LR, Palmer LJ. Population stratification and spurious allelic association. Lancet. 2003, 361, 598-604. doi:10.1016/S0140-6736(03)12520-2

24. Salahshourifar I, Halim AS, Wan Sulaiman WA, Zilfalil BA. Contribution of MSX1 variants to the risk of non-syndromic cleft lip and palate in a Malay population. J HumGenet. 2011,56,755-8. doi: 10.1038/jhg. 2011.95.

25. Huang YQ, Ma J, Ma M, Deng Y, Li YD, Ren HW et al. Association between MSX1 variants 
and oral clefts in Han Chinese in western China. DNA Cell Biol. 2011, 30(12), 1057-61. doi:10.1089/dna.2010.1208.

26. Suzuki Y, Jezewski PA, Machida J, Watanabe Y, Shi M, Cooper ME. In a Vietnamese population, MSX1 variants contribute to cleft lip and palate. Genet Med. 2004,6(3),117-25. doi:10.1097/01.GIM.0000127275.52925.05

27. Tongkobpetch S, Siriwan P, Shotelersuk V. MSX1 mutations contribute to nonsyndromic cleft lip in a Thai population. J Hum Genet. 2006,51(8),671-6. doi:10.1007/s10038006-0006-4

28. Selvi R, Saranya GR, Murthy J, Mary AF, Paul SFD. Chromosomal Abnormality in Individuals with cleft lip or cleft palate. Sri Ramachandra Journal of Medicine, 2009,2(2), 21-24.

29. AI-Adsani AM, EI-Zawahri MM, AI-Bustan SA, Bang RL. Cytogenetic Studies on Cleft Lip and/or Cleft Palate in Kuwait. The Egyptian Journal of Medical Human Genetics, 2003, 4 (1), 35-44.

30. Alkuraya FS, Saadi I, Lund JJ, Turbe-Doan A, Morton CC, Maas RL. SUMO1 haploinsufficiency leads to cleft lip and palate. Science, 2006,313,1751

31. Osoegawa K, Vessere GM, Utami $\mathrm{KH}$, Mansilla MA, Johnson MK, Riley BM.
Identification of novel candidate genes associ ated with cleftlip and palate using array compa rativegenomic hybridisation. $\mathrm{J} \quad$ Med Genet. 2008,45(2),816. 이:10.1136/jmg.200 $\underline{7.052191}$

32. Mukhopadhyay P, Greene RM, Zacharias W, Weinrich MC, Singh S, Young WW Jr et al. Developmental gene expression profiling of mammalian, fetal orofacial tissue. Birth Defects Res A Clin Mol Teratol. 2004,70(12),912-926. DOI: $\underline{10.1002 / \mathrm{bdra} .20095}$

33. Jakobsen LP, Borup R, Vestergaard J, Larsen LA, Lage K, Maroun LL etal. Expression analyses of human cleft palate tissue suggest a role for osteopontin and immune related factors in palatal development. Exp Mol Med. 2009 , 41(2),77-85.

34. Park JW, Cai J, McIntosh I, Jabs EW, Fallin MD, Ingersoll $\mathrm{R}$ etal. High throughput SNP and expression analyses of candidate genes for non-syndromic oral clefts. J Med Genet. 2006, 43(7),598-608. doi:10.1136/jmg.2005.040162

35. Stanier P, Moore GE. Genetics of cleft lip and palate: syndromic genes contribute to the incidence of non syndromic clefts. Hum Mol Genet,2004,13(S1), R73-81 DOI: $\underline{10.1093 / \mathrm{hmg} / \mathrm{ddh} 052}$ 